\title{
Analysis on Technical Efficiency of Hybrid Maize Production in District Mirpurkhas, Sindh
}

\author{
Irfana Noor Memon ${ }^{1, *}$, Sanaullah Noonari ${ }^{1}$, Hakimzadi Wagan ${ }^{1}$, Muhammad Hanif Lakhio $^{2}$ \& Abdul Wakeel $^{1}$ \\ ${ }^{1}$ Department of Agricultural Economics, Faculty of Agricultural Social Sciences, Sindh Agriculture University, \\ Tandojam, Pakistan \\ ${ }^{2}$ Department of Statistics, Faculty of Agricultural Social Sciences, Sindh Agriculture University, Tandojam, Pakistan \\ *Correspondence: Department of Agricultural Economics, Faculty of Agricultural Social Sciences, Sindh \\ Agriculture University, Tandojam, Pakistan. E-mail: sanaullahnoonari@gmail.com
}

Received: February 23, 2016 Accepted: March 14, 2016 Online Published: April 20, 2016

doi:10.5430/mos.v3n2p30

URL: http://dx.doi.org/10.5430/mos.v3n2p30

\begin{abstract}
In order to analyze the technical efficiency of hybrid maize production in Mirpurkhas district of Sindh province, a survey was carried out during the year 2014-15. Empirical model for the total production of maize on farms was used and approximated by Cobb-Douglas production function involving various production associated factors. Technical efficiency for maize farms in sample area was 0.48 and most of the farms were technical inefficient below 0.50 . The values of overall technical efficiency maize farmers ranged from 0.177 to 0.980 . This implies that there is significant scope to increase efficiency levels. The frequencies of technical efficiencies indicated that sample farmers were categorized in three efficiency groups with low $(<90 \%)$, medium $(90-95 \%)$ and high $(>95 \%)$ efficiency and assessed that 90 percent of the maize farms had low efficiency $(<90 \%)$ and remaining 10 percent were highly efficient (above 95\%) in district Mirpurkhas. The poor technical efficiencies imply that the soil quality, inadequate canal water, insect pest and poor extension services could be the causes of this low efficiency. There is significant scope to increase efficiency levels and extension services should be used to increase the technical efficiencies of the inefficient farms. A decline in overall technical efficiencies may be due to a complex of factors and increase in the rate of diffusion of technology and optimal farm management practices encouraged by extension services and programs should increase the technical efficiencies of the inefficient farms in the study area.
\end{abstract}

Keywords: hybrid maize; inefficient; farms; Mirpurkhas; Sindh

\section{Introduction}

Maize grain is a vital nourishment grain and delivers a variety of items as crude material for multi items and quality increases. It contributes 2.1 percent to the worth included agribusiness and 0.4 percent to GDP. Territory under maize crop has diminished to 1130 thousand hectares in 2014-15, demonstrating a decline of 3.3 percent over a year ago's region of 1168 thousand hectares. The creation of maize harvest remained at 4.695 million tons amid 2014-15, demonstrating 5.0 percent diminish in the course of the most recent year generation of 4.944 million tons. The generation diminished because of decline in range sown. Amid 2014-15, the gram beat, one of the significant heartbeats developed in rainfed ranges on minimal grounds recorded generation of 484 thousand tons against the creation of 399 thousand tons amid the same period a year ago, saw a development of 21.3 percent because of expansion in territory and great climate condition. The creation of Bajra, Jawar, Rapeseed and Mustard and Barley saw diminish in its generation by 14.3 percent, 13.4 percent, 9.9 percent and 9.0 percent, separately amid 2014-15 when contrasted with the same period a year ago. The diminishing underway is because of lessening in range sown (GOP, 2015).

Maize is a standout amongst the most potential oats become all around, and is the third after wheat and rice altogether sustenance grain generation. Because of its high versatility and profitability, the development of maize spread quickly around the world and right now it is being delivered in many nations of the world. In India as well, maize is developing as the third most vital product, after rice and wheat. Maize was customarily developed as staple nourishment, fundamentally for family unit utilization, however its interest for food and mechanical uses has 
expanded quickly in the later past. In our nation, more than 50 for each penny of maize produce is being utilized as creature food (Singh et al., 2003).

Maize being the most noteworthy yielding grain crop on the planet is of critical significance for nations such as Pakistan, where quickly expanding populace has officially out stripped the accessible sustenance supplies. In Pakistan maize is third imperative oat after wheat and rice. Maize represents $4.8 \%$ of the aggregate trimmed territory and $3.5 \%$ of the estimation of farming yield. The mass $(97 \%)$ of the aggregate generation originate from two noteworthy areas, KPK, representing $57 \%$ of the aggregate range and $68 \%$ of aggregate creation and Punjab contributes $38 \%$ land with $30 \%$ of aggregate maize grain creation. Almost no maize $2-3 \%$ is created in the area of Sindh and Sindh. Additionally an extremely developing and high yielding segment of maize, the spring maize range and generation in Punjab is not represented, which covers around 0.070 million ha with around 050 million tons of maize grain being delivered. (Shah, 2014). Hence, there is have to examine the generation and specialized effectiveness of the half and half maize so as to prescribe approach prospects for its manageability.

Ordinarily, the effectiveness levels are low when contrasted with the global per section of land efficiency: doubtlessly, a percentage of the variables contributing towards the low profitability are crazy. This wastefulness is likewise termed as specialized wastefulness built up its idea. Comprehensively talking, specialized wastefulness is the inability to deliver most extreme yield from a given level of inputs (Basnayake and Gunaratne 2002). This efficiency has two parts: specialized and allocative. Specialized efficiency is the capacity of a firm to create a maximal yield from a given arrangement of inputs or it is the capacity of a firm to use as unobtrusive inputs as could be allowed for a given level of yield. The previous is called info arranged measures and the last is known as yield situated measures of specialized effectiveness. Profitability can be in wrinkled through more productive usage of assets of ranchers and inputs with current innovation. In this study, efficiency of maize makers of District Chiniot is assessed. Interrelationship between efficiency level and different firm particular components gives valuable approach related data. Primary goal of the study is to figure the specialized effectiveness and determinants of wastefulness of maize producers (Hassan, 2004).

For the most part the homesteads with the same assets are creating diverse per section of land yield, as a result of administration wastefulness. The insufficient or no part of augmentation administrations, poor right of section to credit, occupant development, low efficiency rate, poor interchanges offices, and long separation from business sectors describe wasteful ranches. At present yield level is still up to some degree lower than the capability of our current assortments. Primary limitations to improve maize profitability are unfavorable climate conditions, inaccessibility of information at legitimate time, imperfect plant thickness, late sowing, lacking manure use, deficient water supply, weed infestation, bug bother assault and the determination of unsatisfactory cultivars under a given arrangement of situations. Subsequently, an agriculturist's capacity to build his salary and efficiency level is obliged by various components of which numerous drop out of his control (Tahir et al., 2008). A large portion of the proportions or efficiency components examined as yet are required during the time spent investigation of the records. Their motivation, all in all, is to show a solid or feeble point in the association or operation of the business and to point out the particular stages or edges of the business where more noteworthy administrative consideration is required. What's more, there are different proportions that are regularly utilized as a part of a more broad investigation. They manage the relationship in the middle of expenses and returns, relationship of capital speculation to pay, and the rate of action or turnover of the capital. Taken a toll proportions are midpoints and their extents reflect physical generation efficiency.

Therefore, the present study has been planned to analysis the technical efficiency of maize in district Mirpurkhas of Sindh province with aims to the following objectives:-

\section{Objectives}

1. To study the profile of hybrid maize growers in the Mirpur Khas district Sindh.

2. To estimate the return to scale of hybrid maize growers.

3. To identify issues and suggest policy recommendations.

\section{Methodology}

The technical efficiency of maize production in Mirpurkhas district of Sindh province were investigated during the year 2014-15, using empirical model for the total production of maize on farms, likely to be approximated by 
Cobb-Douglas production function involving various production associated factors. The main purpose of this chapter is to describe the sampling procedure, sample size and method of data collection. This chapter consists of different sections such as: provides as insight into the study area, discusses the selection of the study crop, sampling techniques applied and sample size, questionnaire development and its pre-testing, variables in the analysis study, difficulties faced by the researcher during data collection and the limitations of the study.

\subsection{Overview of the Research Area}

The study was conducted in the mixed cropping system of different talukas of district Mirpurkhas of Sindh province. The district of study has unique history and it was the largest district of the province. Later, the district has been divided into three districts, namely Mirpurkhas, Umerkot and Tharparkar.

\subsection{Sampling Procedure}

Mirpurkhas district has three talukas i.e. Mirpurkhas, Kot Ghulam Muhammad and Digri. A four stage sample design was used for collection of information from the field. First stage units were talukas, second stage units were union councils, third stage units were villages and fourth stage units were farmers. Stratification at the first stage was done by taluka, two union councils were selected from each taluka. Of these six union councils, two villages were selected from each union council and five randomly selected farmers were selected from each village. Thus, categorically a balanced, representative stratum from three talukas of the district was finalized to a size of 100 respondents. For managing the last stage sampling unit i.e. farmers, a list of farmers in each selected village was prepared and necessary information was obtained regarding, name of the farmer, area owned, area rented in/out, area share cropped in/out, ultimate operational farm holding and their location on the water course. The list of farm respondents in each selected village served as frame for sampling. Sample was stratified according to farm size and classified as different farm sizes. In all 100 farmers were selected from the twelve villages, 5 farmers from each village, keeping in view the composition of farm size in the selected villages and their location on the water course.

\subsection{The Questionnaire}

The questionnaire for the survey was designed to illicit for details about maize operations on the farms in the study area. Information concerning, farm size (acres), source of irrigation, age, education etc. were collected. The output and input data were obtained on per farm and per acre basis in the survey.

\subsection{Pre-Testing}

According to Casley and Kumar (1988) a newly constructed questionnaire should be pre-tested on a few pilot respondents in order to identify weaknesses, ambiguities and omissions before it is finalized for the survey itself. Pre-testing provides an opportunity for the researcher to improve the questionnaire by adding something which they feel is missing or by deleting something which is unwanted or changing something that is not clear to the respondents. In this study, a comprehensive questionnaire was established and pre-tested in sample areas. As a result of the pre-testing some minor changes were made. The interviews were conducted in the local language. In some cases, the farmers were not available at the first visit; therefore, the interviewer had to pay a second visit to these respondents.

\subsection{Estimation Method}

Cobb-Douglas production function was used to find out the responsiveness of dependent variable (yield) to independent variables (fertilizer, animal labor, human labor, water application, pesticide application, number of plowing, weeding, farmyard manure, seed rate application and other inputs for maize crop. Following is the conceptual regression model to study relationship between yield and input factors.

According to Heady and Dillon (1960), the Cobb-Douglas function provides:

a) An adequate fit of the data.

b) Computational feasibility.

c) Sufficient degree of freedom to allow for statistical testing.

Cobb-Douglas function in the study was in the form as follows:

$\boldsymbol{Y}_{i}=\boldsymbol{\beta}_{1}+\boldsymbol{\beta}_{2} \boldsymbol{X}_{2}+\boldsymbol{\beta}_{3} \boldsymbol{X}_{3}+\boldsymbol{\beta}_{4} \boldsymbol{X}_{4}+\boldsymbol{\beta}_{5} \boldsymbol{X}_{5}+\boldsymbol{\beta}_{6} \boldsymbol{X}_{6}+\boldsymbol{\beta}_{7} \boldsymbol{X}_{7}+\boldsymbol{\beta}_{8} \boldsymbol{X}_{8}+\boldsymbol{\beta}_{9} \boldsymbol{X}_{9}$

Where,

$\mathbf{Y}=$ Dependent variables (yield)

$\mathbf{X}_{1}=$ Fertilizer use 
$\mathbf{X}_{2}=$ Animal labor use

$\mathbf{X}_{3}=$ Human labor use

$\mathbf{X}_{4}=$ Seed rate application

$\mathbf{X}_{5}=$ Number of plowing

$\mathbf{X}_{6}=$ Pesticide application

$\mathbf{X}_{7}=$ Water application

$\mathbf{X}_{8}=$ weeding

$\mathrm{X}_{9}=$ farmyard manure

$\boldsymbol{\beta}_{0}, \boldsymbol{\beta}_{1}, \boldsymbol{\beta}_{2}, \boldsymbol{\beta}_{3}, \boldsymbol{\beta}_{4}, \boldsymbol{\beta}_{5}, \mathbf{B}_{6}, \boldsymbol{\beta}_{7}, \boldsymbol{\beta}_{8}, \boldsymbol{\beta}_{9}$ are the parameters, which describe the way of function, behave.

For estimating the model, it has been transformed into log linear form by entering log to both sides of equation.

$\log Y i=\beta_{0}+\beta_{1} \log X_{1}+\beta_{2} \log X_{2}+\beta_{3} \log X_{3}+\beta_{4} \log X_{4}+\beta_{5} \log X_{5}+\beta_{6} \log X_{6}+\beta_{7} \log X_{7}+\beta_{8} \log X_{8}+\beta_{9} \log X_{9}$

The data were collected through field survey. The sample of 60 respondents from each cotton, wheat and sugarcane growers was selected through cluster sampling technique. Data were collected from growers by means of questionnaire, designed for the purpose. Data so collected were tabulated analyzed and interpreted in the thesis.

\subsection{Data Limitation}

In the study area, a considerable number of farmers were illiterate and many do not keep records of the inputs and outputs. This study suffers from weaknesses associated with the survey interviews when data accuracy depended heavily on the respondent's ability to recall past information and to answer the survey questions accurately. Such efforts were minimized by re-interviewing the farmers in case of any inconsistencies. However, some errors and discrepancies are unavoidable in this kind of study, despite every precaution.

\section{Results}

The study was carried out during the year 2015 to analysis the technical efficiency of production in District Mirpurkhas of Sindh province Pakistan and to look into the estimate the return to scale of hybrid maize growers and identify issues and suggest policy recommendations.

\subsection{Maize Crop}

The data of descriptive statistics for maize crop in Mrpurkhas district. The data indicated that the average farm to road distance was 2.1 and the standard error was 0.369 kilometer and varied from 1 kilometer to 6 kilometers while the average area on which maize was grown on the sample farms was 12.95 and the standard error was 0.389 acres, but the area under maize varied from 2 acres to 54 acres. The average age level of the respondent farmers in the sample area was 37.1 and the standard error was 2.391 years, but the age of respondents varied from 22 years to 66 years.

The average level of education of the respondent farmers in the sample area was 5 and the standard error was 1.378 years of schooling, but a considerable number of farmers were illiterate being no schooling years as minimum level, while the maximum average level of education in the sample area was 14 years of schooling showing a considerable number of graduate respondent farmers. The data indicated that the average land rent per acre per annum in the sample area was 2725 with the standard error was 135.89 rupees, but the minimum level of land rent was 1500 rupees per acre and the maximum level of land rent per acre was 3500 rupees per acre Similarly, a land tax was being charged at an average level of 304 rupees per acre and all the respondent farmers in the sample area paid the same rate of land tax.

The average number of plowing per acre given to maize area sown in the sample area by the farmers was 3.55 with the standard error was 0.788 , but the number plowing varied from 2 to 5 per acre. The data indicated that the average weddings per acre given to cotton area sown in the sample area by the farmers was 3.20 and the standard error was 0.117 and the number of weeding varied from 2 to 4 per acre, the average number of irrigation per acre given to maize crop sown in the sample area by the farmers was 5.8 and the standard error was 0.137 and the number of irrigation varied from 5 to 7 per acre.

The average number of family labour plus permanent hired adult labour used on the sample farms was 2.3 persons per farm, but the number of family labour plus permanent hired labour varied from 1 as minimum number of laborers 
to 7 as the maximum number of labourers per farm in the sample area. The average quantity of cotton seed per acre used for maize sowing in the sample area by the farmers was 6.50 with the standard was $0.917 \mathrm{~kg}$, and the seed quantity varied from 5 to 10 kilograms per acre. It was further noted that the average quantity of DAP fertilizer per acre given to maize in the sample area was 0.85 and the standard error was 0.166 bags, varied from 0 to 2 bags per acre. The average nitrophos fertilizer per acre given to maize in sample area was 0.80 and the standard error was 0.117 bags, varied from 0 to 2 bags per acre, while quantity of urea fertilizer per acre given to maize crop in the sample area was 1.85 with the standard error was 0.082 bags per acre varied from 1 to 2 bags per acre. The average bags of nitrate fertilizer per acre given to maize in the sample area were 0.90 and the standard error was 0.123 bags per acre, varied from 1 to 2 bags per acre. The average quantity of pesticides per acre applied to maize in the sample area was 2.55 and the standard error was 0.114 liters varied from 2 to 3 liters per acre. The average production of maize yield per acre at the sample farms was 29.35 mounds, showing a minimum yield of 16 mounds, while the maximum yield of 40 mounds (Table-1).

Table 1. Descriptive Statistics for Assessment of Efficiency Level of Maize Crop Growers

\begin{tabular}{lllll}
\hline Variables & Mean values & Stand Error & MinimumValue & Maximum Value \\
\hline Distance from road (km) & 2.1 & 0.369 & 1.00 & 6.00 \\
Area of cotton (acres) & 12.95 & 2.391 & 2.00 & 54.00 \\
Age (Years) & 37.10 & 2.391 & 22.00 & 66.00 \\
Education (Years) & 5 & 1.378 & 0 & 14 \\
Land Rent (Rs/acre) & 2725 & 135.893 & 1500 & 3500 \\
Land Tax (Rs/acre) & 304 & 0 & 304 & 304 \\
Plowing (Number) & 3.55 & 0.788 & 2 & 5 \\
Weeding (Number) & 3.20 & 0.117 & 2 & 4 \\
Irrigation (Number) & 5.80 & 0.137 & 5 & 7 \\
Labours (Number) & 2.90 & 0.323 & 1 & 7 \\
Seed rate (kg/acre) & 2.30 & 0.091 & 2 & 2.50 \\
DAP (Bags) & 0.85 & 0.166 & 0 & 2 \\
Nitrophos (Bags) & 0.80 & 0.117 & 0 & 2 \\
Urea (Bags) & 1.85 & 0.082 & 1 & 2 \\
Nitrate (Bags) & 0.90 & 0.123 & 1 & 2 \\
Pesticides (Liters/acre) & 2.55 & 0.114 & 2 & 3 \\
Yield (Mounds/acre) & 29.35 & 1.616 & 16 & 40 \\
\hline
\end{tabular}

\subsection{Estimates of Stochastic Frontier Production}

The maximum likelihood estimates of the parameters of the stochastic frontier production function are obtained by using the computer programme, 'Frontier 4.1' developed by Coeli (1996). The parameter estimates are presented in Table-2 along with their standard errors and t-values.

The Cobb Douglas production function was found to be an adequate representation of the data, given the specification of the corresponding Translog Frontier Model. The value of coefficient for nitrogen application to maize variable is 1.33 , indicates that one percent increase in the nitrogen increase the maize production by 1.33 percent. The value of coefficient for phosphorus variable is 1.34 , denotes that one percent increase in the phosphorus increase the maize production by 1.34 percent, while coefficient value for potassium variable is 0.99 , indicates that one percent increase in the potassium, increase the maize production by 0.99 percent. Coefficient value for pesticides variable is 0.93 , indicates that one percent increase in the pesticides; increase the maize production by 0.93 percent and coefficient value for seed rate variable is 0.31 showing that one percent increase in the seed rate, increase the maize production by 0.31 percent. The coefficient value for sowing date variable is 1.39 , indicates that one percent earliness in the sowing date, increase the maize production by 1.39 percent and coefficient value for seed quality variable is 0.38 showing that one percent improvement in seed quality, increase the maize production by 0.38 percent. The value of coefficient for irrigation numbers variable is 1.49 indicates that increase of irrigation, increase the maize production by 1.49 percent. 
Table 2. Maximum Likelihood Estimates for Parameters of Stochastic Frontier Production for Maize Farmers in Mirpurkhas District

\begin{tabular}{llll}
\hline \multicolumn{1}{c}{ Variable } & \multicolumn{1}{c}{ Coefficient } & \multicolumn{1}{c}{ Standard Error } & T-value \\
\hline Nitrogen & 1.3386 & 0.0134 & 5.10 \\
Phosphours & 1.340 & 0.0423 & 3.68 \\
Potassium & 0.9991 & 0.0831 & -0.00 \\
Pesticides & 0.9328 & 0.1348 & -0.71 \\
Seed rate & 0.3186 & 0.0012 & 2.25 \\
Sowing rate & 1.3931 & 0.0562 & 3.68 \\
Seed quantity & 0.3834 & 0.09842 & 2.72 \\
Irrigation & 1.4950 & 0.0543 & 0.65 \\
\hline
\end{tabular}

\subsection{Technical Efficiency}

Technical efficiency for maize growers is examined using stochastic production function approaches. The empirical application used farm-level data from different areas of district Mirpurkhas. Mean efficiency scores are invariant of the method of estimation under the assumption of constant returns to scale. On average the technical efficiency of irrigated maize farming in Mirpurkhas district was 0.48. Maize is the most important agricultural commodity in Mirpurkhas district of Sindh province, but not a single maize farm reached techncial efficiency of 1.0 and most of the maize sample farmers had technical efficiency below 0.50 (Table-3).

The comparative poor performance in terms of overall technical efficiency is in the southern and eastern regions of the district. This may be purely due to the differences in soil quality and inadquate availability of canal irrigation. Most of the south and east parts of Mirpurkhas district are tailends of canals and there is severe water shortage in these areas. However, in the weastern areas and north, the condition of canal water is satisfactory. The mean values of overall technical efficiency range from 0.177 to 0.980 (Table-3).

Table 3. Technical Efficiencies of Sample Maize Farmers Obtained Using the Cobb-Douglas Stochastic Frontier Production Function Model

\begin{tabular}{cc}
\hline Number of farms & Maize farms \\
\hline 1 & 0.508 \\
2 & 0.177 \\
3 & 0.763 \\
4 & 0.267 \\
5 & 0.570 \\
6 & 0.252 \\
7 & 0.228 \\
8 & 0.562 \\
9 & 0.449 \\
10 & 0.166 \\
11 & 0.697 \\
12 & 0.354 \\
13 & 0.291 \\
14 & 0.273 \\
15 & 0.515 \\
16 & 0.980 \\
17 & 0.534 \\
18 & 0.968 \\
19 & 0.383 \\
20 & 0.669 \\
Average & $\mathbf{0 . 4 8 0}$ \\
\hline
\end{tabular}




\subsection{Frequencies of Technical Efficiencies}

Factors under lying higher efficiency than the average of the sample could make interesting study. For this purpose, the sample farmers were categorized in three efficiency groups with low $(<90 \%)$, medium $(90-95 \%)$ and high $(>95 \%)$ efficiency as indicated in Table-4. The above table exhibited that 90 percent of the maize farms in Mirpurkhas district fallen under the category of low efficiency $(<90 \%)$, while zero sample farms producing maize in the Mirpurkhas district fallen in the category of medium efficiency (90-95\%). However, two of the 20 farms producing maize fallen under the category of high efficiency (above 95\%) and the percentage of the farms under this category remained 10 percent of the total sample farms producing maize in district Mirpurkhas.

Table 4. Frequencies of Technical Efficiencies for Maize Farmers in the Mixed Farming System of District Mirpurkhas

\begin{tabular}{lll}
\hline Range of technical efficiencies & Number of farmers & Percent \\
\hline$<0.90$ & 18 & 90.00 \\
0.90 to $>0.95$ & 0.00 & 0.00 \\
$>0.95$ & 02 & 10.00 \\
Total & 20 & 100.00 \\
\hline
\end{tabular}

\section{Conclusion and Suggestions}

Analysis of technical efficiency for maize production in district Mirpurkhas of Sindh province concluded that there are significant possibilities to increase efficiency levels in maize production on average in Mirpurkhas district.

\subsection{Suggestions/Recommendations}

1) The poor technical efficiencies imply that the soil quality, inadequate canal water, insect pest and poor extension services could have had an influence on technical efficiency in the sample area.

2) There is significant scope to increase efficiency levels and extension services should be used to increase the technical efficiencies of the inefficient farms.

3) In addition, there exists a decline in overall technical efficiencies due to a complex of factors and increase in the rate of diffusion of technology and optimal farm management practices encouraged by extension services and programs should increase the technical efficiencies of the inefficient farms in the study area.

4) The government should announce the support price of maize crop on the basis. Quick and cheap transport and communication facilities should be provided to farmers at farm level. Farm to market, roads should be constructed by government

5) Good quality and high yielding varieties of seed should be supplied before sowing of maize crop in Pakistan.

6) Supplies of genetically improved and high quality seed needs to be insured by the government. There is a need to strengthen research activities.

7) Sindh Seed Corporation should produce hybrid varieties of seed in sufficient quantity to meet the increasing demand of farmers

\section{References}

Addai \& V. Owusu. (2014). Technical Efficiency of Maize Farmers across Various Agro Ecological Zones of Ghana Kwabena Nyarko. Journal of Agriculture and Environmental Sciences, 3(1), 149-172

Ahmed, B., \& Hassan S. (2005). Technical Efficiency of Wheat Farmers in Mixed Farming System of the Punjab, Pakistan. International Journal of Agriculture and Biology, 7(3), 431-435.

Amos T.T. (2007). An Analysis of Productivity and Efficiency of Small holder Cocoa Farmers in Nigeria. Journal of Social Sciences, 15(2), 127-133.

Anupama, R., Singh P., \& Kumar R. (2008). Technical Efficiency in Maize Production in Madhya Pradesh: Estimation and Implications. Agricultural Economics Research Review, 18(3), 305-315. 
Arega, D., Alenea L., \& Hassanb R. M. (2009). The efficiency of traditional and hybrid maize production in eastern ethiopia: an extended efficiency decomposition approach. Journal of African Economies, 15(1), 91-116.

Baloi, E., J. Rebecca \& Tshilambilu. (2011). Technical efficiency in maize production by small-scale farmers in Ga-Mothiba, Limpopo Province, South Africa. Journal of Plant Protection, 13(3), 136-140.

Basnayake, B.M.J.K., \& L.H.P. Gunaratne. (2002). Estimation of technical efficiency and it's determinants in the tea small holding sector in the mid country wet zone of Sri Lanka. Sri Lankan Journal of Agricultural Economics, 4, 137-150.

Betty, W.K. (2008). Technical efficiency in Kenyan's maize production: an application of the stochastic frontier approach. Journal of Plant Protection, 32(1), 456-462.

Binici, T., C.R. Zulauf, O.O. Kacira \& K. Bahri. (2006). Assessing the Efficiency of Maize Production on the Harran Plain, Turkey. Outlook on Agriculture (IP Publishing Ltd), 35(3), 227-232. http://dx.doi.org/10.5367/000000006778536729

Chalraborty, K., M. Sukant \& J. Phillip. (2002). Maize Farmers' Technical Efficiency: Stochastic and Nonstochastic Production Function Approaches. Agricultural and Resource Economics Review, Oct., 1-2.

Chirwa E. W. (2007). Sources of Technical Efficiency among Small holder Maize Farmers in Southern Malawi, AERC Research Paper 172, African Economic Research Consortium, Nairobi November 2007.

Collins, D.O. (2013). Measurement of Technical Efficiency and Its Determinants among Maize Farmers in Asante Akyem North Municipality. International household survey network, 48(1), 548-552.

Elibariki, M., \& A. Gasper. (2005). Estimation of Technical Efficiency in Tanzanian Sugarcane Production: A Case Study of Mtibwa Sugar Estate Out Growers Scheme. Economic and Development Papers, Mzumbe University 1.1(2005): pp. 28-46.

Fried H.O, Lovell C.A.K \& S.S Schmidt. (2008). Efficiency and Productivity, In H. O. Fried. A. Knox Lovell \& S. S. Schmidt (eds.), the Measurement of Productive Efficiency and Productivity Change (pp. 3-91). New York:

Ghulam, S., Z. U. Haq, F. Ali, K. Mahmood, M. Shah \& I. Khan. (2009). Technical efficiency of maize farmers in various ecological zones of AJK. Sarhad J. Agric., 25(4), 156-160.

Government of Pakistan (2015). Pakistan Economic Survey 2014-15. Economic Advisor's Wing, Finance Division, Islamabad.

Haque, M. E., M.A. Quddus \& K.M. Rahman. (2002). Estimation of Gross and Net Technical Efficiencies of Wheat Production in Bangladesh Under Two Alternative Functional Forms. Bangladesh Journal of Agricultural Economics, 25(2), 85-101.

Hassan, S. (2004). An analysis of technical efficiency of wheat farmers in the mixed farming system of the Punjab Pakistan. Ph.D. Thesis, Department of Environmental and Resource Economics (Farm Management), University of Agriculture, Fasialabad.

Hassan, S. (2004). An Analysis of Technical Efficiency of Wheat Farmers in the Mixed Farming System of the Punjab, Pakistan. M.Sc. (Economics) Thesis submitted to the Department of Environmental \& Resource Economics/ University of Agriculture, Faisalabad, Pp. 132.

Hussain, I., F. Marikar \& W. Jehangir. (2000). Productivity and Performance of Irrigated Wheat Farms Across Canal Commands in the Lower Indus Basin. Journal of Agricultural Economics, 45(1), 44-49.

Idris, A.A., R. O. Aminu \& S. B. Ibrahim. (2014). Technical efficiency of maize production in Ogun State, Nigeria. Journal of Plant Science, 7(2), 55-60.

Khanna, G. (2006). Technical Efficiency in Production and Resource Use in Sugar Cane: A Stochastic Frontier Production Function Analysis. Working Paper No 15-2006, HEI Working Papers from Economics Section, The Graduate Institute of Intl. Studies, Geneva. Retrieved from http://hei.unige.ch/sections/ec/

Kibaara, B.W., \& M.M. Kavoi. (2009). Application of stochastic frontier approach model to assess technical efficiency in Kenya's maize production. Journal of Agriculture, Science and Technology, 32(1), 132-135.

Kuriuki D.K., Ritho C.N., \& Muneik. (2008). Analysis of the Effect of Land Tenure on Technical Efficiency in Smallholder Crop production in Kenya. Conference on International Research on Food Security, Natural Resource Management and Rural Development. Tropentag. 
Ladunni, O. A., A. J. Joseph \& O. David. (2013). Technical Efficiency of Smallholder Maize Farmers in Nigeria: The Stochastic Frontier Approach. Global Journal of Current Research Aduba, 11(4), 132-140.

Marenya, P.P., \& Barrett, C.B. (2007). Household-level determinants of adoption of improved natural resources management practices among smallholder farmers in western Kenya. Food Policy, 32(4), 515-536. http://dx.doi.org/10.1016/j.foodpol.2006.10.002

Morgan, C., Mutoko, N. Cecilia, K.A. James \& L.E. Oliver. (2011). Soil Management and Technical Efficiency of Small-scale Maize Farmers in Northwestern Kenya. Kenya Agricultural Research Institute, 32(1), 982-990.

Naqvi, N., S. A. Ali \& A. Muhammad. (2014). Estimation of technical efficiency and it's determinants in the hybrid maize production in district Chiniot: a Cobbdouglas model approach. Pakistan Journal of Agricultural Sciences, 51(1), 181-188.

Osamah, K., A. Mansi, Z. H. Mahmood \& N. K. Abbas. (2015). Estimating the Profit Cost Functions, Economic and Technical Efficiencies of Corn Production in Babylon Province in Iraq.

Pandey, L. M., P.A.L. Suresh \& M. Ruthyunjaya. (2003). Impact of Zero-Tillage Technology in the Rice Oryza Sativa : Wheat Triticum Aestivum System of Foothills of Uttaranchal State, India. Indian Journal of Agricultural Science (Indian J. Agric. Sci.), 73(8), 432-437.

Parkish, Ashok \& Farikh. (1995). Measurement of Economic Efficiency in Pakistani Agriculture. American Agriculture Economics Association, 675-685.

Shah. (2014). Measurement of technical efficiency in the north-west frontier provinces of Pakistan. Journal on Agricultural Economics, 45, 132-138

Singh, D., \& Khosla, R.K. (2003). Post-harvest food grain losses in India: A review. Agricultural Situation in India, 33(8), 499-500.

Spencer \& H. Milton. (1993). Contemporary Microeconomics ( $8^{\text {th }}$ Ed.). Worth Publishers, 24-25.

Susan, C., T. Kalinda \& G. Tembo. (2010). Stochastic Frontier Analysis of the Technical Efficiency of Smallholder Maize Farmers in Central Province, Zambia. Journal of Agricultural Science, 98(1), 321-326.

Syed, A., A. Naqvi \& M. Ashfaq. (2013). Technical efficiency analysis of hybrid maize production using translog model case study in District Chiniot, Punjab (Pakistan). Journal of Agricultural sciences, 43(2), 132-140.

Tahir, M., Tanveer, A., Ali, A., Abbas, M., \& Wasaya, A. (2008). Comparative yield performance of different maize (Zea mays L.) hybrids under local conditions of Faisalabad-Pakistan. Pakistan Journal of Life and Social Sciences, 6, 118-120

Thomson, R., L. Kalinda \& G. Tembo. (2014). Stochastic Frontier Analysis of the Technical Efficiency of Smallholder Maize Farmers in Central Province, Zambia Susan China. Journal of Agricultural Economics, $32(1), 257-262$.

Wier, A.T., J.W. Mullins \& J.M. Mills. (1998). Bollgard Maize Update and Economic Comparisons Including New Varieties. Proceedings of the Beltwide Maize Conferences, 2, 1039-1040.

Wilfred, T., L. Nyangena \& O. M. Juma. (2011). Impact of Improved Farm Technologies on Yields: The Case of Improved Maize Varieties and Inorganic Fertilizer in Kenya. International Journal of Applied Agricultural Sciences, 11(3), 67-73.

Wirat Krasachat. (2000). Measurement of Technical Efficiency in Thai Sugarcane Production. The Chao Phraya Delta: Historical Development, Dynamics and Challenges of Thailand's Rice Bowl, Pp. 1-5.

Yusuf Tashrifov. (2006). The Impact of Agricultural Reforms on Tajikistan's Maize Production Efficiency. Zagreb International Review of Economics and Business, 9(2), 117-134. 